\title{
investment: Socially engaged art and the financialization of social impact
}

\section{Emily Rosamond}

Arts University Bournemouth, UK

\begin{abstract}
This article examines the implications of the financialization of social impact and the emerging social impact bonds (SIBS) market for socially engaged art practices. How do SIBs, which allow for investment in social impact metrics, shift the broader contexts through which the value of social impact is understood in art discourses? In the British context, recent projects by Assemble, Open School East and others do important social work, yet echo the logic of the social investment market by outsourcing social impact. Rather than dismissing socially engaged art initiatives as having been recuperated by financialized capitalism, I suggest the need to develop new ways of achieving a double reading of these works as they relate to - and upset the distinctions between - stakeholder and bondholder valuation.
\end{abstract}

\section{Keywords}

Socially engaged art, social impact bonds, social impact investing, financialization

\section{Introduction}

Rirkrit Tiravanija's Untitled (Free) (1992): an art gallery transformed into a makeshift kitchen, where visitors could come for conversation and Thai food. Suzanne Lacy's Storying Rape (2012): a choreographed conversation that brought together media, politicians, law enforcers and activists in order to discuss how to reframe narratives concerning violence against women. The Turkish art collective Oda Projesi's ongoing collaborations with their neighbors in an apartment in Galata, Istanbul (1997-present). These are but a few projects in a long tradition of socially engaged art. Such projects often seek to avoid producing a rarefied, reified art object. Instead, they focus on collaboration, community, and social space. Often, such projects attempt to make a positive impact on a particular community. As curator Maria Lind (2004) summarized Oda Projesi's work: "Activities vary, but a common denominator is that they are not about showing or exhibiting a work of art but about using art as a means for

\section{Corresponding author:}

Emily Rosamond, Arts University Bournemouth, Poole, Dorset BH12 5HH, UK.

Email: erosamond@aub.ac.uk 
creating and recreating new relations between people through diverse investigations and shaping of both private and public space". This description could easily be extended to characterize the aims of many other socially engaged projects.

Since the late 1990s, socially engaged art projects have become increasingly visible within art discourses. Art historians and critics have waged heady debates as to what constitutes the value of such projects. For instance, should their value be evaluated ethically, or aesthetically? What conceptions of, and interventions in, a social space are valuable - to whom, and why? Often, such analyses take for granted that socially engaged artworks are at least partially opposed to the art market, insofar as their value is understood as social, ameliorative and/or discursive, rather than financial (as in art practices revolving around the sale of costly art objects). Yet even if this is true for certain socially engaged projects, it has become less obvious that social and financial values can be so easily separated from one another. In light of this, I want to examine a recent development which has the potential to drastically reshape the broader context for socially engaged artworks, yet whose implications for socially engaged art have yet to be systematically theorized. I call this development the financialization of social impact.

By the financialization of social impact, I mean the development of financial products that encourage private investment in specific social impact metrics. In particular, I focus on the development of the social impact bond (SIB) since 2010 as paradigmatic of a broader, emerging phenomenon of the financialization of social impact. SIBs are contracts between investors and the public sector, administered through intermediary companies, which outline a commitment to pay for improvements in social outcomes that could lead to public savings, at least in theory. For instance, Social Finance, Ltd. has created social impact bonds to finance outcomes from prisoner rehabilitation in Peterborough to schemes for helping rough-sleepers in London. Investors provide start-up capital for charity-run social programs; if agreed social impact targets are met, governments pay investors at a fixed rate of return. SIBs attempt to realize a mutuality of interest between investors, governments and non-profits seeking to make a difference to at-risk groups.

How might the financialization of social impact necessitate new understandings of the contexts for socially engaged art practices to come, thereby impacting how their value is to be understood? This article is a preliminary and necessarily speculative attempt to recontextualize some recent socially engaged art discourses with respect to the financialization of social impact. As the SIB market is still quite new, it is too early to say whether the specific investment structures initiated there will directly impact the art market on a broad scale (for instance, by funding particular socially engaged art projects, based on pricing their ability to improve specific social impact metrics). However, since I am taking SIBs to be paradigmatic of a broader phenomenon of financialized social impact, it will not be my aim to trace such direct connections. Rather, I wish to examine the abstract alignments that SIBs instantiate by aligning governments', investors', service providers' and beneficiaries' interests - what Maurizio Lazzarato might understand as the asignifying semiotics of a social diagram. This is a structure of networked relation or command (for instance, within a team of office workers) that influences the shape of communications, and thereby orders the political work directors and other decision-makers undertake when setting agendas for an organization, even without producing a direct sign (Lazzarato, 2014: 113-14).

After a section situating my use of the term financialization and analysing the social alignments instantiated by the social impact bond, I then analyse how these new abstract alignments - especially those between investors and beneficiary subjects - might complicate, challenge and nuance the ways in which contemporary art discourses understand the value of 
social impact, with reference to some recent examples: Assemble's Turner Prize win, and Open School East and School of the Damned's responses to the introduction of $£ 9,000$ per year university tuition fees across the UK in 2012, after a fee cap rise following the Browne Review in 2010. Finally, I situate these claims within a history of socially engaged art discourses.

Throughout, it will become apparent that the financialization of social impact, exemplified by the social impact bond, nullifies claims (already criticized from many other angles) that acts of social engagement (packaged, at times, within art practices) sit separate from the market, ameliorate alienation, or put something 'genuine' back into the reified realm of commodity exchange. Yet, given that social impact bonds envision, and instantiate, new ways to intertwine social investor interests and stakeholder interests (in other words, the participants in a project, and/or those affected by its interventions), it is necessary to experiment with analytical methods for evaluating socially engaged art practices within a financialized, post-SIB context without simply dismissing socially engaged projects as exemplars of financialization. Thinking of SIBs as abstract social diagrams exemplary of a broader contextual shift suggests that financialized social impact requires the development of ways to read the valences, and implications, of socially engaged art projects doubly, as they relate to, on the one hand, investor interests and, on the other hand, stakeholder interests. To borrow a term often used in the social investment community, such projects need to be understood according to a 'double bottom line'. In other words, they need to be seen as both social and immediately financial; as both participated-in by stakeholders and productive of investment-images of participation within (and beyond) the broader commerce of art discourse.

\section{Social impact bonds and the financialization of social impact}

In order to develop a double reading of stakeholder and investor interests in socially engaged art, I must further develop my sketch of the financialization of social impact by referring both to discourses on financialization and by detailing the development of SIBs. In this section, my principal claim will be that, as an abstract social diagram, SIBs (which exemplify the financialization of social impact) bring investor and stakeholder interests into a new alignment. In subsequent sections, I introduce this claim into the context of contemporary art, arguing that the new alignment necessitates a discursive shift in socially engaged art discourses.

\section{Financialization}

Firstly, in what sense do I mean 'financialization'? With over a decade of scholarship on financialization to reckon with, the meaning of this term is not self-evident, and my definition of the financialization of social impact involves recombining different strains of financialization discourses. As Van der Zwan (2014) has argued, there are, broadly speaking, three tendencies within studies of financialization. One strain understands financialization as a new regime of accumulation, and thus emphasizes the figure of the rentier as a paradigm of non-productive accumulation. A second strain focuses on corporate structuring, and emphasizes the role of shareholder value as part of a new distribution of managerial power. Finally, a third strain focuses on financialization as a form of governmentality, which encourages people to understand their daily lives in financial terms.

My approach to the financialization of social impact combines (and slightly refocuses) elements of the first and third strains in Van der Zwan's schema. On the one hand, seen from the perspective of investors, SIBs express a new regime of accumulation which encourages 
social impact investors to speculate on social impact, while governments respond to a crisis of capital accumulation by inviting social impact investors to inject privatized social welfare services with start-up funds. On the other hand, the development of social impact metrics operates through a financialization of daily life. Social impact investors speculate on behavioral shifts in beneficiary populations, who may be encouraged to improve their personal lives (for instance, by not reoffending after they have left prison) through participating in programs funded by SIBs. Such changes of personal habit, in turn, are precisely what investors speculate on when they purchase SIBs. In short, SIBs embed investors' stakes into the everyday personal and social experiences of beneficiaries, whether the latter are aware of this or not.

The financialization of social impact is but one arena in which, as Chiapello (2015) has recently argued, inherently financial forms of valuation are colonizing non-financial activities. Although such a colonization of daily life by the financialized logic of pricing risk is indeed taking place, this need not necessarily be understood by the beneficiaries whose behavioral changes are being priced. Many accounts of the financialization of daily life emphasize the ways in which individuals are trained to understand their own lives in financial terms (for instance see Martin, 2002). The way of situating the term 'financialization' I have presented here instead focuses on the ways in which there is a doubling of financialized perspectives, whereby investors are given a stake in improving beneficiaries' habits, which is aligned with, yet still remains separate from, the stake the latter might have in changing their own habits. Whether beneficiaries of a social impact project are aware of it or not, the investor's perspective - and the logic of investment that comes with it - creeps in as a background precondition. It is part of an abstract social diagram that aligns beneficiaries' and investors' interests, even if on quite uneven terms (as we shall see below).

\section{The rise of the social impact bond}

To get a clearer sense of how SIBs function as an unconscious background condition for social impact scenarios, it is necessary to sketch the rise of the social impact bond. In this section, I am not aiming to give a technical account of SIBs, which have complex implications for business, law, risk assessment, impact measurability and policy. Instead, I give an overview of SIBs oriented towards understanding the social diagram - the alignments between stakeholder and investor interests that might be most transferrable to socially engaged art discourse. As Schram (2015: 155, 229) argues, the basic concept that would eventually return in the form of SIBs was developed in 1988 by Ronnie Horesh, a New Zealand economist who proposed what he called "social policy bonds". Horesh believed that the investment structure he invented would suit high-risk, experimental programs (for unemployment, homelessness, and child welfare, among others) for which governments were not willing to assume risk (Schram, 2015: 156). Over twenty years later in 2010, the UK became the world's SIB innovation leader, promoting social welfare improvements more broadly, rather than using SIBs to back particularly experimental programs.

The world's first SIB was managed by Social Finance, London - a financial intermediary company founded in 2007 to address a "funding shortfall in the social sector" (Social Finance, 2016). Social Finance gathered approximately $£ 5$ million in investment capital from charities and private investors for a pilot program, launched on 10 September, 2010, which aimed to reduce recidivism rates among short-term male prisoners (serving sentences of less than 12 months) at Peterborough prison (Disley et al., 2011: 3). This SIB set its social impact target at 
a $10 \%$ reduction in recidivism for each of its three cohorts, or a $7.5 \%$ reduction overall across the three cohorts for the seven years of the full term (Disley et al., 2011: 3; Birkwood, 2014). The final cohort did not enter the program, as the Ministry of Justice cancelled the pilot (which cut the SIB's full term down from seven years to six). Investors missed an opportunity for early payout in 2014, when a study by QinetiQ (a multinational defence technology company based in Britain) and the University of Leicester concluded that recidivism had dropped by $8.3 \%$ and not the 10\% required for an early payout (Birkwood, 2014). Nonetheless, Social Finance Ltd. remains hopeful that, based on the two cohorts remaining in the program, investors will see returns in 2016 (Birkwood, 2014). This remains to be seen at the time of writing.

Although commonly associated with the Cameron government in the British context, the SIB was initially a Blair-era Labour initiative, which the subsequent Conservative-Liberal Democrat coalition government adopted. Thus, Callanan notes, there was enthusiasm in the investor community about SIBs' potential to 'cross the floor', uniting the interests of a broader spectrum of parties and practitioners (Miller et al., 2012). Although the first British pilot was cancelled midway through, the SIB has gained much traction worldwide since 2010, with the UK as the world leader. As of early 2014, there were 14 SIBs in the UK, which targeted a range of social problems, most of which could be addressed through support aimed toward behavior modification. These include reducing recidivism, providing foster care and addressing homelessness (Instiglio, 2014; Kalin, 2014). There are also several SIBs emerging in the US, along with pilot programs in many other countries (among them Canada, Ireland, Australia, India, Uganda and South Africa). In addition, intermediary companies such as Social Finance are developing ways to expand the logic of SIBs into the development impact market in the Global South, leading to the development impact bond (DIB) (Kalin, 2014).

The social impact bond is, of course, not entirely unique; it bears the marks of a longer history of tools and techniques for valuating and operationalizing social impact. This history would include, for instance, the broader development of Payment by Results (PBR) public policy instruments (of which SIBs are one variety) (Disley et al., 2011: 1). PBR instruments allow governments to make payments contingent on independently verified results. The SIB is by no means the first or the only instrument of the financialization of social impact. Yet whereas previous PBR schemes paid service providers directly for results (meaning that charities delivering social services would have to wait until a program had ended to receive payment), the SIB addresses this time gap by introducing investors and intermediaries into the mix, which allows service providers to get capital upfront. Their innovative structure instantiates a unique geometry of connections between government agencies, external organizations, investors, service providers, and beneficiaries. In doing so, SIBs exemplify, instantiate and even theorize, in their very form, an incisive social diagram, a kind of financialized social diagram which epitomizes a new investment-logic of social impact. As a newly emerging (and potentially, in the future, hegemonic) configuration of relations between shareholders and stakeholders in social impact, SIBs have much to teach socially engaged art discourses about the relations between finance and society as they might develop in years to come.

\section{SIBs as an abstract social diagram}

What I am calling the abstract social diagram of SIBs can best be explored with the help of Figure 1 below, which visualizes the basic structure of aligned interests that Peterboroughstyle SIBs imagine and enact. In the center of the arrangement, an external organization (in 
the case of the Peterborough bond, Social Finance, Ltd.) develops the financial product. In doing so, it mediates between a government agency (in this case, the Ministry of Justice), a number of investors (here, $£ 5$ million from individuals and charities, including the Lankelly Chase Foundation) (Birkwood, 2014), and one or more service providers (including the St. Giles Trust). The latter, in turn, work with a beneficiary population. Governments agree to pay for targets in a fixed term, according to a fixed rate by outcome. (In this case, the pilot was initially intended to last seven years, though it has been cut short - and a $7.5 \%$ overall reduction leads to a payback from governments to investors.) Missing in the diagram are the external assessor(s) - in the Peterborough case, QinetiQ, University of Leicester and RAND Europe - who independently evaluate whether the desired impact outcomes have been attained. SIBs are not technically bonds, which pay a fixed interest (Schram, 2015: 155; Whistler et al., 2014). SIBs pay by result. As Callanan notes (in Miller et al., 2012), the outcomes for SIBs, among investors, are conceptualized as a 'double bottom line' (DBL or 2BL): a potential fiscal gain paired with a positive social impact. There are many kinds of investors, Callanan notes, who are showing interest in SIBs worldwide. Even for what she terms the 'socially agnostic investor' (a euphemism for one concerned with profit more than social impact), SIBs have a strong potential appeal in terms of portfolio diversification, since the success or failure of a program to reach a target social impact outcome might be uncorrelated with market growth.

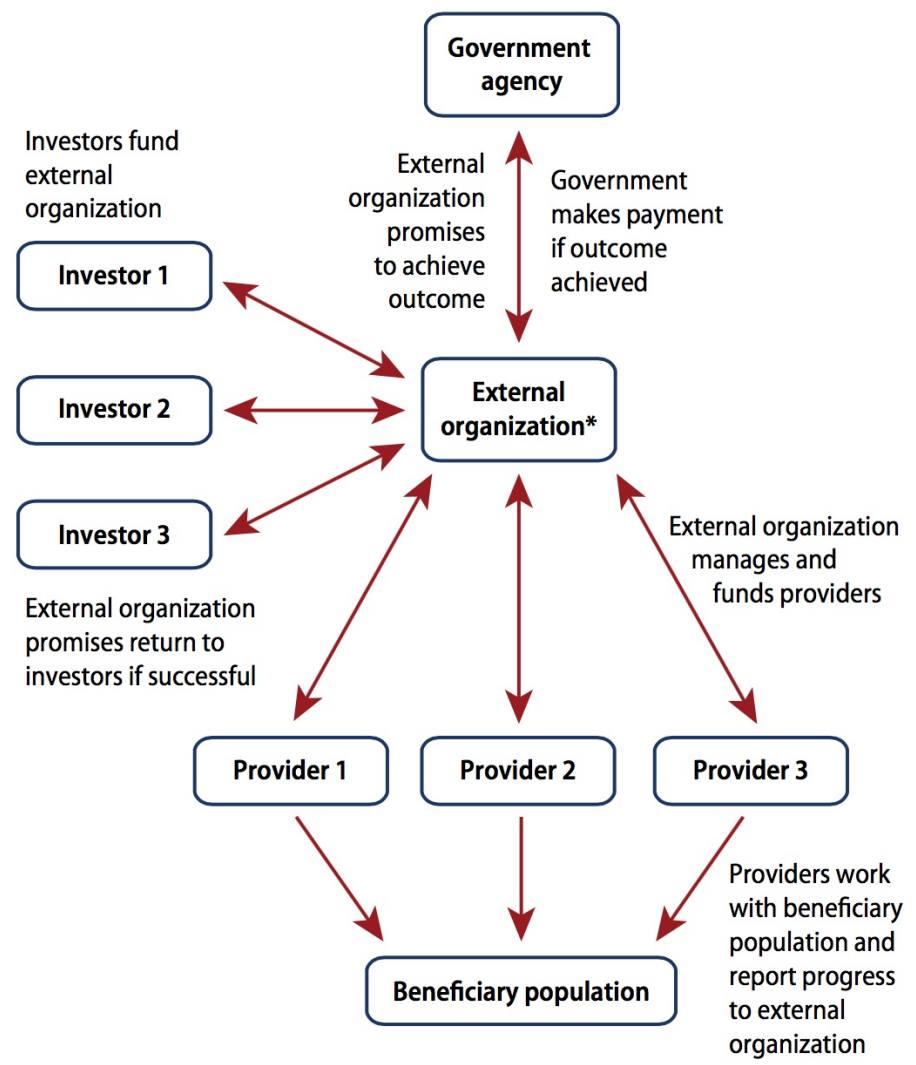

Figure 1. The Peterborough-style social impact bond. Source: Kohli, Besharov and Costa (2012)

The social diagram that SIBs instantiate is, indeed, so effective and appealing to parties at all levels, in interlocking the varied interests of its participants, that Callanan remarks that, when she and her colleagues were first introduced to SIBS, they wondered if the latter were Ponzi schemes; they seemed too good to be true (in Miller et al., 2012). At a SIB panel at the 
Social Capital Markets conference in 2014, panellists on 'The Complex Anatomy of Social Impact Bonds' panel representing a range of perspectives on SIBs - including representatives from investment firms backing and assessing risk in SIBs, legal teams contributing pro-bono work to drafting complex SIB contracts, service providers and government officials - spoke of a broad range of benefits to SIBs. These included a greater ability to focus on outcomes and thus increase the effectiveness of social programs; greater flexibility for non-profit service providers, since the latter can innovate and change course when needed, because of the emphasis on outcome, rather than a particular methodology; an increased ability of nonprofits to scale up their services to benefit larger groups; and the ability to bring many players to the table such as investors and non-profits in order to increase mutual understanding (Whistler et al., 2014). Gary Graves, chief operating officer of Santa Clara County, remarked that his county was even willing to pay for an SIB-backed outcome - a reduction in homelessness - which would not lead to a future government saving. This was because the County believed that a reduction in homelessness was an important social aim. It also viewed an SIB-backed program as the most efficient way to achieve this outcome.

\section{Critiques of SIBS}

A number of critics have noted drawbacks to this new alignment of interests. These include difficulties with devising metrics for social impact; difficulties with measurement and risk assessment; and a tendency to favour (and fund) only outcomes that can be readily quantified (Whistler et al., 2014). More fundamentally, as Schram (2015) notes, one of the main criticisms of SIBs is that they effectively privatize the welfare state, quietly taking power and control over social welfare programs out of the public interest - and effectively allowing rich investors to siphon profits off of social impact, by means of a speculative (and predatory) valuation of "projected future government savings". Dowling and Harvie (2014: 870), for their part, argue for the need to analyze what they call the "political economy of big society" instantiated through SIBs: "the state - partly as a response to its own fiscal crisis - is further retreating from the sphere of social reproduction, placing the associated costs onto the unpaid realms of the home and the community".

While investors front the capital, it is largely workers in the non-profit sector (not to mention the served populations, who must invest effort in the programs in order for them to succeed) who, perhaps out of a genuine urge to restore something in the social fabric, will work for investors' profit. (As will become clear in subsequent sections, this analysis could be extended to include artists who invest their free labor in social projects.) This results in a "deepening of capitalist disciplinary logics into the social fabric" (Dowling and Harvie, 2014: 870-71). Governments, so the criticism goes, should ideally still be willing to pay for social programs, to keep them thoroughly in the purview of public interest. Even Andi Phillips, social investing expert and Vice President of Goldman Sachs, agrees: "I am right there with all of you who say that, but that is not the world we live in" (in Whistler et al., 2014). Social needs exceed what governments are currently able or willing to pay for; thus, SIBs, in Phillips' view, represent a best-case scenario for achieving social impact outcomes. The double bottom line preserves and protects social impact outcomes, by infusing them with capital. Yet, as Dowling (2016) and Ogman (2016) point out, such a perspective should be questioned. After all, as Dowling (2016: 12) notes, a variety of institutions that promote SIBs have undertaken "considerable efforts to produce consent to impact investing". Furthermore, in the case of the Peterborough SIB, for instance, the SIB-backed scheme did reduce recidivism, but it did not save governments 
money. Thus, governments found themselves increasing expenditure overall and "forming special 'outcome funds' to pay investor returns" (Ogman, 2016: 59).

The double bottom line lauded by Phillips exemplifies the financialization of social impact: a new way to bring the 'greater social good' (particularly as it is conceptualized, and targeted toward a philanthropic response to disadvantaged groups who would cost the state) into line with the interests of the investing class. It does so such that it privileges investor gains over government savings as it outsources social impact funding. Moreover, as Dowling (2016: 12) reminds us, there is widespread concern that any savings governments are likely to make as a result of SIB-backed initiatives may ultimately be at the cost of care workers, who might face more precarious working conditions and lower pay when dependent on SIB-backed care work. In Dowling's view, SIBs reflect a form of 'accumulation by dispossession' (Harvey, 2004), whereby "public funds are being privatized through the use of financial instruments such as SIBs" (Dowling, 2016: 9). This accumulation by dispossession is arguably all the more effective for the ease with which SIBs create seemingly seamless alignments between investor and stakeholder interests, even as they fail to disrupt the vast power imbalances between investors, charities and beneficiaries.

\section{Investor-stakeholder alignments}

To get an even more vivid sense of how SIBs' abstract social diagram produces new investorstakeholder alignments, it is useful to briefly consider the ways in which Social Finance promotes its own social value. New forms of financial backing - and with them, new forms of performative pressure - rest squarely on beneficiaries' shoulders, whose very re-habituation becomes investors' bread and butter. In a promotional video on Social Finance's website, a reformed former Peterborough prisoner helped by the world's first SIB-backed programs speaks to the camera, perfectly performing the shared stakes and distributed investment of the double bottom line. "Although it's me that's changed, it's through them, if you like," he says:

It's knowing that you've got that support there, if you need someone to ring up, and you need a bit of help... whether it's with your housing, whether it's with your benefits, or whatever... rather than... just having one option: and that's to commit crime. ... It's massive for me. It makes me feel good inside. It makes me feel better all round, really. You have to work just as hard as everybody else... If it weren't for... the support group, I wouldn't have understood that, simple as - 'cause I didn't have this frame of mind last year. (Social Finance, 2014)

The camera cuts to a field of flowers, gently blowing in the breeze. The reformed prisoner seems, for all intents and purposes, to be genuinely happier, better adjusted and well supported. In his better adjustment, he enacts the double bottom line: the attitudes and affects that accrue investment-image status through the video, and tacitly whisper Social Finance logic. Reproductive care - care for the social through care for character - becomes both a personal interest and a distributed investor interest, as it is expropriated to the upper echelons of the investment world.

Thus far I have developed an account of the financialization of social impact through five lenses: (1) from the perspective of discourses on financialization; (2) by considering the rise of the SIB as an exemplar of the financialization of social impact; (3) by considering the SIB as abstract social diagram which exemplifies the financialization of social impact; (4) through critiques of SIBs; and (5) by examining the ways in which Social Finance has 'voiced' its social 
impact through the voice of one of its beneficiaries. These avenues for analysis reveal a social diagram that innovatively aligns stakeholder and investor interests through a double bottom line, such that investors' interests seem to be consistent with social impact.

\section{Parables of social engagement and investment}

This diagram represents a newly prevalent alignment of stakeholder and investor interests in social impact according to a double bottom line of social and financial gain. How might this new alignment serve as a context for socially engaged contemporary art practice? In this section, I develop some initial prospective methods for differentiating between doubled stakeholder and investor interests in socially engaged art practices. I do so, first, by examining two scenes in which social improvement acts as theme, as goal, and perhaps even as fetish in recent British art. I then discuss how these projects' value might be understood with respect to the double bottom line inherent to the financialization of social impact, which acts as a broader background condition against which the events and images associated with each of these projects unfolds.

Let us begin with Scene One. The Stratford, London-based architecture and design collective Assemble win the 2015 Turner Prize at an awards ceremony at Tramway, Glasgow. They were nominated for their housing projects at Granby Four Streets, Liverpool. Aggravated by a glut of predatory, top-down regeneration plans for the city, the collective sought to collaborate with local residents and support their vision for the area by renovating dilapidated old houses and protecting them from demolition. They launched the Granby Workshops through their Turner Prize exhibition: a platform through which local residents can make and sell a range of design products using recycled materials from refurbished sites, the profits of which are then reinvested back into the community.

Assemble's project was widely praised by both participants and onlookers. Nevertheless, many viewed the Turner Prize jury's selection of an architectural collective with apprehension. Even Assemble were surprised. One member, featured in a TateShots video, describes the nomination as quite uncomfortable for the project and the group, since it rarefied local residents' activities by labelling them "art" (Tate, 2015). Another, when asked whether the group's project was 'art' in a Guardian article, remarked: “For us it's not that important: it's an academic discussion. We are more interested in doing good projects ... Sometimes that's about doing really good plumbing" (Higgins, 2015). As Gayford (2015) notes, the decision to view Assemble's project as art came neither from the group itself, nor from their participants, but from the curator who nominated them. A strange geometry of designation unfolds, which trades in social impact. The boldness of the curator's pronunciation - as if to wave a magic wand that turns 'projects' into 'art' - speaks to the odd relationship (expressed by the Prize far more than the project) between professionalized, sanctioned art world actors and social outcomes. On the one hand, the Turner Prize selection expresses a keenly felt desire, within and outside of the art world, to counter austerity measures and the privatized, financialized regeneration outcomes to which these lead. On the other hand, citizens of the hermetic upper echelons of the art world, arguably, enact a voracious - perhaps even predatory - appetite for outsiders, for impact, for the look and feel of social engagement.

Scene Two unfolds across a few locations within and beyond East London. Responding to soaring tuition fees and unmanageable financial hardship for artists and students, a spate of open art schools emerges. Open School East, which occupies a former community centre and library in East London, opened its doors in 2013. It offers a free study programme for emerging artists, with the aim to foster exchanges between artists and the broader public. 
School of the Damned (SOTD) produced its first graduating class of its non-accredited MA art program in 2014. Their program is run entirely by participating students, with some help from an ever-evolving roster of visiting lecturers and artists, many of whom teach at universities elsewhere. No money changes hands. SOTD runs nomadically; they exist, as they say, as "a website and a google drive account" (School of the Damned, 2016). Both Open School East and School of the Damned have been widely applauded for the quality of their work, and for providing a much-needed alternative to the university in an austerity context. Indeed, they understand their stance as outsiders to the financialized field of higher education as political. School of the Damned's website declares: “The school does not receive any money, pay for any resources using funds, or charge its students admission. The school runs outside institutional systems of funding as an active political position. Guests are invited on a pre-agreed exchange of time for time labour" (School of the Damned, 2016).

Certainly, neither Assemble, nor Open School East, nor School of the Damned work with SIBs directly. Nor do they intentionally adopt a financialized conception of social value or social impact. In fact, the aim might be quite the opposite; particularly in the second scene, the free art schools understand themselves as actively resisting financialization by resisting the remunerated exchange of services. Nonetheless, both of these cases involve circulating images of a positive social impact (whether intentionally or not) within and beyond the boundaries of the respective projects (for instance, as participants experience these impacts, but also as such impacts are reported on, framed and circulated in news articles, videos, and so on by non-participants). Images of these socially impactful projects circulate within a broader social context in which the financialization of social impact is quietly but pervasively taking hold. Thus, quite aside from the question of whether these projects have a positive impact on their participants (which they certainly seem to do), or whether they directly instantiate a financialized conception of social impact, there is another, tactical question as to how such projects participate in, collude with or resist broader shifts in the valuation of social impact. Thus, the value of such projects must be understood doubly, according to both the stakeholder interests of their participants, and the 'investor interests' of all those who benefit from circulating images, narratives, accounts and/or metrics relating to those social impacts.

What might be learned from these projects for developing a 'double bottom line' reading of stakeholder and investor interests in socially engaged art projects? Further, how could one develop such a reading, so that it is not focused on a direct engagement with the financialization of social impact, but rather understands the financialization of social impact as a part of the broader social context within which such projects operate (particularly in the British context)? In other words, how can one transpose the diagrammatic doubling of stakeholder and investor interests that SIBs instantiate, and use this to inform a doubled stakeholder/investor account of the value of socially engaged art?

For one thing, adopting a double bottom line reading of socially engaged projects counters the facile claim that such projects - and particularly those that do not directly generate financial value - are necessarily outside of, or antithetical to, financial investment or exchange. As much as Open School East and School of the Damned provide a much-needed alternative to costly education, they also operate in a context in which a financialized logic of social impact directly operationalizes social reproductive labor that is outsourced into the volunteer realm. After all, as Dowling and Harvie argue (2014), the SIB extends the British Conservative Party's failed 'Big Society' ideology by other means. As Dowling and Harvie argue, Big Society - the Cameron government's vision of a voluntarist conservatism, which outsourced government services by mobilizing citizens' desire to care for their neighbors, and encouraging them to volunteer for the public good - clearly failed as an ideology. 
Nevertheless, Dowling and Harvie argue, this ideology still continues to operate through the outsourcing of government services to independent, private social service providers via SIBs. In a similar vein, Sanford Schram (2015: 153) has argued that "Social impact bonds represent nothing less than the financialization of the welfare state". Indeed, broadly speaking, the voluntarist desire to care for at-risk populations - to do the work of social reproduction - has never been so closely, and so effectively, aligned with investor interests. Given this realignment of voluntarism with investor interests, a given socially engaged art project's opposition to financialized valuation may only pertain to one of its two 'bottom lines'.

Furthermore, many debates in contemporary art tend to understand 'social engagement' as something that happens within the boundaries of a particular participatory project - in other words, between live, active participants - even though in many projects, pictures of these participants then circulate as images of participation for a secondary social network of image-consumers, within and beyond the circuitries of the art world. As images and writings on participatory projects circulate beyond the bounds of a particular place, time and social group, they sometimes generate value for those who have invested in these images of social investment, such as the curator who nominated Assemble for the Turner Prize. Thus, a model of the value of socially engaged art practices needs to account for both stakeholder values and investor values. These 'investors' could include financial investors, but also those who have staked something of their careers or reputation on the value of a particular socially engaged project. In other words, there needs to be a distinction in socially engaged art discourses between the perspectives of stakeholders (the communities, networks and people who participate in a given project, willingly or otherwise), and those of investors: the broader world of curators, writers, buyers, art professionals and enthusiasts who stake something of their reputations and/or finances as they write, produce accounts, or circulate images, enthusiasm or criticism of a particular project.

I have framed the concept of investment, here, as predominantly a psychic, and secondarily a monetary claim on a subject's interestedness in/on a particular object of investment. (Of course, such values extend, and are extended by, directly financial senses of the term investment.) In both of these senses, a social impact's being outside of direct financial exchange does not guarantee that it is antithetical to the financialization of social impact in a 'Big Society' context. Further, there are not only stakeholders in socially engaged art projects, but also investors, who invest financially and psychically in circulating images of social engagement. Today's socially engaged projects operate within a society in which it is becoming easier and easier to align stakeholder and investor interests, by doubling the kinds of stakes that both of these groups have in daily life. Therefore, adopting a 'double bottom line' method of analyzing the value of these projects might help to analyze the (often quite significant) social value of these projects for stakeholders, while also acknowledging that these social values are not necessarily antithetical to financialized values of investors.

\section{Socially engaged art discourses}

This distinction has the potential to nuance discussions of socially engaged art discourses within a context in which social impact is becoming financialized, producing new alignments between stakeholders' stakes and shareholder interest. In order to appreciate this, it is helpful to have a provisional sense of where these discourses come from. Here, I provide a very brief overview of some of the most predominant arguments on socially engaged art practices, as they have been theorized and understood from the late 1990s to 2007 (just before the financialization of social impact, exemplified by SIBs, takes off beginning in 2010). Many of 
these writers' positions will be familiar to readers with a background in contemporary art; since these texts have been widely written about elsewhere, I will only provide a sketch here. Nonetheless, even a glimpse of this terrain reveals a stubborn focus, which seeps into more current discussions, around what are arguably the wrong questions in an era of social investment: namely, whether or not - and to what extent - projects are properly 'open', 'participatory' or 'inclusive' of their participants.

We will begin with Bourriaud's Relational Aesthetics (2009), and end with more nuanced critiques of Bourriaud by Judith Rodenbeck (2007) and Stuart Martin (2007). First published in 1998, Relational Aesthetics provides an account of 1990s art practices that aimed to provide visitors with a social encounter, rather than with a reified art object. Bourriaud pronounced such art's power to restore the social bond, and to revisit the political dimensions of social relations. In a highly influential text, Bishop (2004) criticized Bourriaud's assumption that the social space of a relational artwork could be straightforwardly 'open' or 'inclusive'. Rather, following Laclau and Mouffe, Bishop advocates for an antagonistic conception of social space. She argues that the most interesting relational art practices actively address or reveal something of the antagonism that always, already fractures social spaces. (In a world of SIBs, stakeholder and shareholder interests are so gracefully aligned that perhaps it becomes all the more difficult to pull them apart, to 'reveal' the antagonism in the split between the two halves of the double bottom line.)

Two years later, Bishop (2006b) takes a slightly different target for a similar critique: writings on socially engaged art practices which judge the efficacy and value of art practices by how "inclusive" and "genuinely collaborative" they are, thereby reducing aesthetic judgments of artworks to ethical ones. For instance, Kester (2004) insists on the political importance of conversation in a post-9/11 world, in which truly open dialogue seems all but impossible. Lind (2007) has valued projects for their degree of openness to the communities they facilitate or serve. In light of this critical tide toward conversation and collaboration, Bishop questions the insistence that socially engaged art need produce effective dialogue between disparate parties. She reasserts the importance of aesthetics in socially engaged art criticism, and advocates for side-lining ethical judgment when evaluating collaborative, socially engaged artworks. Throughout the 2000s, Bourriaud's Relational Aesthetics inspired a spate of other critiques. Rodenbeck (2007), for example, argues that Bourriaud's analysis structurally and strategically disavows earlier social experiments by Fluxus artists - which were far edgier, more fraught, and, oftentimes, more uncomfortable for participants than anything produced in the smoother international circuits of the 1990s art world. Stuart Martin (2007) takes Bourriaud to task for a lack of clarity around what, in his view, is Relational Aesthetics' tacit task: an immanent critique of the commodity form.

In various ways, all of these arguments revolve around the tensions between an ameliorative, oceanic sociality and an alienated, antagonistic sociality. Arguably, we could map such tensions into the newly financialized realms of the SIB by imagining that amelioration and antagonism have simply become interlocked in a more refined fashion within the context of financialized social space. But this approach would not speak adequately to the specific relational logics of financialized social impact - the ways in which governments, investors, carers and beneficiaries align themselves in this newly operationalized climate for social impact. Moreover, all of these discourses understand that socially engaged art practices will travel further than their participants and will be extended into space and time as stories and images. Yet further work is needed to theorize adequately the different stakes in social engagement proffered by participants and online onlookers, the latter of which might view investment-images of social projects, rendered in photos, captions, 'buzz' or art historians' 
writings. There is something in this differential distribution between participating and looking at the images of socially engaged art projects that aligns very closely with the shared stakes, but distributed investment, that course though the 'double bottom line' scenarios of social impact investing, which realign stakeholder and investor interests.

\section{Conclusion: The double bottom line}

In light of SIBs and the financialization of social impact, it would be very easy to dismiss Assemble's Turner Prize win as another curator's predatory move, turning people's community project into an investment-image for the art world. It would be almost as easy to dismiss the open art school as yet another example of the 'Big Society', which encourages investors to profit from unremunerated activities with social aims. A school such as SOTD, one could argue, responds to the broader contexts of financialized social impact with something like a divestment strategy. Only by divesting investor logic from higher education, so the argument goes, can education truly be free. Yet all of this unwittingly echoes the logics of financialized social impact. It forces participants into an informal economy, essentially expropriating to students and volunteers the heady tasks of producing, and reproducing, the school's values. The open school's silent echo is the social impact bond, which whispers yet another (perhaps more innovative, more complicit, more refined) version of its expropriative logic.

Yet it would be neither interesting, nor fair, to end with such conclusions. At a time in which investment capital has so innovatively woven its expropriations into the social fabric, it is all too easy to claim that 'everything' - even the care for one's neighbor - has been appropriated by investor interests, as enacted through innovative financial product design. Nothing, indeed, remains 'untouched' by these distributed investment-logics; and yet to make such a blanket claim would be to dismiss any potential in these projects for resistance. It is simply not the case that no such potential exists. Both Assemble's projects and the open schools of London have had dramatic impacts on the communities and lives of their stakeholders, and in so doing have rearranged the social fabric of their respective cities. Nonetheless, these projects operate in an austerity context, in which it has become more difficult to 'cleanly' separate stakeholder from investor interests. Indeed, just as investors backed Social Finance-designed SIBs, so the Turner Prize 'backs' Assemble, turning its project into an investment-image.

As an art project that circulates as an image of social engagement, it is not possible for it to remain entirely separate from the cultural logics of social impact investment, with all the obligatory complicity that this implies. Yet even the desire to be separate from participation in the logics of investment does not get one very far. As a critical stance, in an age of the financialization of social impact, this desire (expressed in much art criticism and many art projects) may well hold open the idea, the hope, the possibility of an action actively opposed to investment logic. Yet in holding open this hope of opposition, the ostensibly 'uninvested' project misses an opportunity for strategic intervention into the cultural logics of investment.

As Feher argues (2013), if, as activists, one does not like neoliberalism, the best thing one can do about it is to be neoliberal: that is, to actively take on the logics and languages of its investment structures, in order that one's activism can be rendered legible within the arenas in which it must operate. Liberal-era activism, Feher remarks $(2009,2015)$, such as labor unions, often addressed the employer as a source of oppression. To do so, such activism took on board the assumptions written into the liberal-era logics underpinning the workplace: for instance, the idea that there was a fundamental distinction between alienable labor in the workplace and inalienable labor in the home. Precisely because of their complicity with liberal- 
era logics of capital, activists made effective interventions (for instance, reducing the hours in the work day). In the neoliberal era, oppression comes from investors, not employers as such. (A common response to workplace complaints given by employers is: "but we must keep the investor happy'.) Thus, a fundamental question for neoliberal-era activism, Feher argues, is how to effectively address the investor as a source of oppression. In other words, how can the position of the investee best be mobilized as a position of resistance?

Perhaps, according to this logic, what is needed most from socially engaged art practices is that they experiment with their status as investees. This might involve not so much a futile attempt to shelter one's project from the logics of social investment, so much as embracing the double bottom line as an operational logic. As art writers (particularly working in the British context), it is our task to not simply repeat the clichés of complicity, assuming any trades in investment-images of social engagement to be artistic and political compromises. Nor should we focus on accusing specific socially engaged projects of echoing the logics of financialized social impact. (This echo is all but obligatory, all but unavoidable.) Rather, perhaps we need to focus on how projects thoughtfully engage with the distinctions between shared stakes and distributed investment, which run through such projects and the images of social impact they, in turn, produce. Assemble, after all, might have been uncomfortable with the rarefied gaze with their participants' becoming-investment-image - which their Turner Prize nomination made all but compulsory. Nevertheless, they found a way to counter-strategize, to turn the Turner's investment logics to their own purposes, by using the Turner exhibition publicity to launch the Granby community's shop. Such acts suggest that there are new ways to activate diagrams of relation between stakeholder and investor interests, to acknowledge and intervene in the new distributions of stakes and investment.

\section{Acknowledgments}

I would like to thank Emma Dowling and David Harvie, whose paper at the 6th Critical Finance Studies Conference in Amsterdam, 2014, first introduced me to SIBs. I would also like to thank two anonymous peer reviewers and the editors for helping me improve this article.

\section{References}

Birkwood, S. (2014) Peterborough prison social impact pilot fails to hit target to trigger payments. Third Sector. Available at: <http://www.thirdsector.co.uk/peterborough-prison-social-impact-bond-pilotfails-hit-target-trigger-repayments/finance/article/1307031/>. Accessed 7 April 2016.

Bishop, C. (2004) Antagonism and relational aesthetics. October, 110 (Fall): 51-79.

Bishop, C. (2006a) Participation. Cambridge, MA: MIT Press.

Bishop, C. (2006b) The social turn: Collaboration and its discontents. Artforum, 44(6): 179-85.

Bourriaud, N. (2009) Relational Aesthetics, translated by S. Pleasance and F. Woods. Dijon: Les

Presses du Réel.

Calinescu, M. (1987) Five Faces of Modernity: Modernism, Avant-Garde, Decadence, Kitsch, Postmodernism. Durham, NC: Duke University Press.

Cave, S., Williams, T., Jolliffe, D. and Hedderman, C. (2012) Peterborough Social Impact Bond: An Independent Assessment. London: Ministry of Justice Research Series.

Chiapello, E. (2015) Financialization of valuation. Human Studies, 38(1): 13-35.

Cohen, Sir R. (2011) Harnessing social entrepreneurship and investment to bridge the social divide.

Paper presented at the EU Conference on the Social Economy, Brussels, 18 November.

Disley, E., Rubin, J., Scraggs, E. et al. (2011) Lessons Learned from the Planning and Early 
Implementation of the Social Impact Bond at HMP Peterborough. London: UK Ministry of Justice. Available at: <https://www.gov.uk/government/publications/social-impact-bond-at-hmppeterborough/>. Accessed 1 April 2016.

Disley, E. and Rubin, J. (2014) Phase 2 Report from the Payment by Results Social Impact Bond Pilot at HMP, Peterborough. London: Ministry of Justice Analytical Series.

Dowling, E. (2016) In the wake of austerity: Social impact bonds and the financialization of the welfare state in Britain. New Political Economy, DOI: 10.1080/13563467.2017.1232709.

Dowling, E. and Harvie, D. (2014) Harnessing the social: State, crisis and (big) society. Sociology, 48(5): 870-86.

Egbert, D. (1967) The idea of 'avant-garde' in art and politics. American Historical Review, 73(2): 33966.

Esposito, R. and Pelsinger, S. (2014) Social Impact Bonds 101. Available at: <https://www.youtube.com/watch?v=_Uunl4uMOog>. Accessed 1 April 2016.

Feher, M. (2009) Self-appreciation: Or, the aspirations of human capital [Translated by I. Ascher]. Public Culture, 21(1): 21-41.

Feher, M. (2013) The neoliberal condition and its predecessors: Redemption, fulfillment, appreciation. Operative Thought Lecture Series, Department of Visual Cultures, Goldsmiths, University of London. 20 November.

Feher, M. (2015) Thank you for sharing: The social life of human capital. Operative Thought Lecture Series, Department of Visual Cultures, Goldsmiths, University of London, 28 January.

Foster, H. (2003) Arty party. London Review of Books, 25(23): 21-22. Available at: <http://www.Irb.co.uk/v25/n23/hal-foster/arty-party/>. Accessed 14 October 2016.

Fox, C. and Albertson, K. (2011) Payment by results and social impact bonds in the criminal justice sector: New challenges for the concept of evidence-based policy? Criminology and Criminal Justice, 11(5): 395-413.

Gayford, G. (2015) Martin Gayford on Assemble and the worrying implications of the Turner Prize. ArtNet News, 11 December. Available at: <https://news.artnet.com/art-world/martin-gayford2015-turner-prize-winners-391148/>. Accessed 4 April 2016.

Harvey, D. (2004) The new imperialism: Accumulation by dispossession. Socialist Register, 40: 63-87. Harvie, J. (2011) Democracy and neoliberalism in art's social turn and Roger Hiorns' Seizure.

Performance Research, 16(2): 113-23.

Higgins, C. (2015) Turner Prize winners Assemble: 'Art? We're more interested in plumbing'. The Guardian, 8 December. Available at: <http://www.theguardian.com/artanddesign/2015/dec/08/assemble-turner-prize-architects-arewe-artists/>. Accessed 4 April 2016.

Instiglio (2014) SIBs worldwide map. Available at: <https://orgs.law.harvard.edu/lids/files/2014/02/SIBs-Worldwide-Map.jpg/>. Accessed 5 April 2016.

Joy, M. and Shields, J. (2013) Social impact bonds: The next phase of third sector marketization? Canadian Journal of Nonprofit and Social Economy Research, 4(2): 39-55.

Kalin, S. (2014) Innovation in financing international development projects. Harvard Law and International Development Society, 1 February. Available at: $<$ https://orgs.law.harvard.edu/lids/2014/02/01/innovation-in-financing-internationaldevelopment-projects/>. Accessed 5 April 2016.

Kester, G. (2004) Conversation Pieces: Community and Communication in Modern Art. Oakland, CA: University of California Press.

Kohli, J., Besharov, D. and Costa, K. (2012) Fact sheet: Social impact bonds - A brief introduction to a new financing tool for social programs. Center for American Progress, 12 April. Available at: 
<https://www.americanprogress.org/issues/general/news/2012/04/12/11406/fact-sheetsocial-impact-bonds/>. Accessed 3 April 2016.

Lazzarato, M. (2014) Signs and Machines: Capitalism and the Production of Subjectivity, translated by J.D. Jordan. Los Angeles, CA: Semiotext(e).

Lind, M. (2004) Actualization of space: The case of Oda Projesi. Transversal, 10(1). Available at: <http://eipcp.net/transversal/1204/lind/en/>. Accessed 30 August 2016.

Lind, M. (2007) The collaborative turn. In: Billing, B, Lind, M. and Lars, N. (eds.) Taking the Matter into Common Hands: Contemporary art and Collaborative Practices. London: Black Dog, 15-31.

Martin, R. (2002) Financialization of Daily Life. Philadelphia, PA: Temple University Press.

Martin, S. (2007) Critique of relational aesthetics. Third Text, 21(4): 369-86.

McHugh, N. et al. (2013) Social impact bonds: A wolf in sheep's clothing? Journal of Poverty and Social Justice, 21(3): 247-57.

McKay, K. (2013) Evaluating Social Impact Bonds as a New Re-entry Financing Mechanism: a Case Study on Re-entry Programming in Maryland. Annapolis, MD: Department of Legislative Services.

Miller, M., Callahan, C., Palandjian, T. and Liebman, J. (2012) Social impact bonds webinar panel. McKinsey and Company, 15 May. Available at: <https://www.youtube.com/watch?v=wdU2tLqT5HA/>. Accessed 5 April 2016.

Ogman, R. (2016) Social impact bonds: A ‘social neoliberal' response to the crisis? In: Schönig, B. and Schipper, S. (eds.) Urban Austerity: Impacts of the Global Financial Crisis on Cities in Europe. Berlin: Theater der Zeit, 58-69.

Rodenbeck, J. (2007) The open work: Participatory art since silence. Institute for Distributed Creativity. Available at:

<http://distributedcreativity.typepad.com/idc_events/2006/01/the_open_work_p.html/>. Accessed 18 October 2015.

Rudd, T., Nicoletti, E., Misner, K. and Bonsu. J. (2013) Financing Promising Evidence-Based Programs: Early Lessons from the New York City Social Impact Bond. New York, NY: MDRC.

Schiller, R. (2013) Capitalism and financial innovation. Financial Analysis Journal, 69(1): 21-25.

Schram, S. (2015) The Return of Ordinary Capitalism: Neoliberalism, Precarity, Occupy. Oxford: Oxford University Press.

Shamir, R. (2008) The age of responsibilization: On market-embedded morality. Economy and Society, 37(1): 1-19.

Silvestri, A. (2012) Critical Reflections: Social and Criminal Justice in the First Year of Coalition Government. London: Centre for Crime and Justice Studies.

School of the Damned (2016) FAQ. School of the Damned. Available at: <http://schoolofthedamned.com/>. Accessed 4 April 2016.

Social Finance Ltd. (2014) Peterborough social impact bond. Good Deals 2013. Available at: <http://www.socialfinance.org.uk/videos/good-deals-2013-sib-case-study-2-one-service/>. Accessed 2 April 2016.

Tate Modern (2015) Turner Prize 2015 artists: Assemble. Available at: <http://www.tate.org.uk/whatson/tramway/exhibition/turner-prize-2015/turner-prize-2015-artists-assemble/>. Accessed 4 April 2016.

van der Zwan, N. (2014) State of the art: Making sense of financialization. Socio-Economic Review, 12(1): 99-129.

Warner, M. (2013) Private finance for public goods: Social impact bonds. Journal of Economic Policy Reform, 16(4): 303-19.

Whistler, C. et al. (2014) SOCAP14: The complex anatomy of social impact bonds. Third Sector Capital Partners. Available at: <http://www.thirdsectorcap.org/video-the-complex-anatomy-of-socialimpact-bonds-at-socap14/>. Accessed 29 March 2016. 